\title{
Analysis of farmers' willingness to participate in pasture grazing programs: Results from a discrete choice experiment with German dairy farmers
}

\author{
M. Danne ${ }^{1}$ and O. Musshoff \\ Department of Agricultural Economics and Rural Development, Georg-August-Universität Göttingen, Platz der Göttinger Sieben 5, \\ D-37073 Göttingen, Germany
}

\begin{abstract}
Over the last decades, the usage of pasture for grazing of dairy cows has decreased considerably. Pasture grazing programs initiated by dairy companies try to counteract this trend. The present paper investigates farmers' willingness to participate in such grazing programs. A special aim was to quantify the price premiums farmers require for program participation and to identify determinants influencing the premium level. The empirical analysis is based on a discrete choice experiment with 293 German dairy farmers. Models are estimated in terms of willingness to accept. It was found that farmers have no substantial preference for whether the pasture grazing program is financed by the food industry, a governmental scheme, or the dairy company. However, an extension of the annual or daily grazing period results in a decreasing willingness of farmers to participate in a pasture grazing program. In addition, farmers decline the option of a feeding standard prescribing the use of only green fodder when offered an alternative program that merely reduces the amount of concentrated feed or maize silage in the diet. Farmers' with an aversion toward program participation have a significant higher price demand for fulfilling the program requirements. Furthermore, the required price premiums increase with growing milk yields and a greater number of cows kept on the farm. However, if the availability of pasture is high, farmers are more likely to participate. The estimated price premiums and factors influencing farmers' willingness to participate found by this study should be considered by dairies and policymakers to gain insights into the design of possible pasture grazing programs from the perspective of farmers. Thereby, paying price premiums to farmers may increase the attractiveness of pasture
\end{abstract}

Received February 18, 2017.

Accepted May 25, 2017.

${ }^{1}$ Corresponding author: michael.danne@agr.uni-goettingen.de grazing, which could finally result in an extended usage of pasture grazing.

Key words: pasture grazing program, farmers' preferences, discrete choice experiment, willingness to accept

\section{INTRODUCTION}

The dairy industry has changed considerably in terms of production methods, products, and processing over the last decades. This change is characterized by the concentration of milk production on fewer, but larger, farms and a substantially increased annual milk production per cow (Gillespie et al., 2009; Reijs et al., 2013). As part of this development, cows have less pasture access (Burow et al., 2013; Reijs et al., 2013). However, grazing is associated with improved health and welfare for dairy cows (Burow et al., 2013) and satisfies the increasing demand of consumers for products with high nutritional value and sensory quality (Ellis et al., 2009; Slots et al., 2009). This added value results in consumers' willingness to pay (WTP) for pasture-grazed milk (Ellis et al., 2009; Wolf et al., 2011; Weinrich et al., 2014).

For farmers, this condition provides the opportunity to receive a higher milk price by producing value-added milk. This is of particular interest because the high volatility of fluid milk prices and feed costs as well as the growing gap in the farm-retail price asymmetry affect the economic viability of dairy farms (Government Accountability Office, 2009). Considering both the advantage of pasture-based dairy farming as a low-cost strategy (Tozer et al., 2003) and the opportunity to benefit from value-added milk, pasture grazing might thereby be an approach for farmers to remain competitive. One possibility to generate a monetary surplus from pasture-grazed milk is participation in a pasture grazing program as offered by some dairy companies in the Netherlands, the United States, and Denmark, for example (Reijs et al., 2013). These dairies have already established milk from pasture as a premium product 
and are thus able to realize higher prices and pay farmers an incentive for producing pasture-grazed milk.

Previous studies (White et al., 2002; Gillespie and Nehring, 2014) have often compared the characteristics of pasture-based dairy farms and confinement systems without focusing on the farmers' willingness to participate in a pasture grazing program. Therefore, the objective of this paper is to assess the willingness of dairy farmers to participate in a pasture grazing program. In particular, we aim to analyze to what extent specific program requirements and monetary incentives influence the willingness of farmers to participate. In addition, we investigate how the farmers' willingness to participate is affected by the farm structure and farmers' characteristics. Considering the estimated price premiums and factors influencing farmers' willingness to participate is useful for dairies and policymakers to gain insights into the design of possible pasture grazing programs from the perspective of farmers.

The study seeks to understand farmers' perceptions by conducting a discrete choice experiment (DCE) with dairy farmers in Germany. Farmers' preferences and willingness to accept (WTA) participation in a pasture grazing program are analyzed using a mixed logit model (MLM) in WTA space. With this approach, we are building on previous studies in the fields of agricultural and environmental research estimating farmers' WTA (e.g., Christensen et al., 2011; Schulz et al., 2014; Schreiner and Latacz-Lohmann, 2015). All of these studies estimate the WTA in preference space, which, unfortunately, often results in unrealistic and invalid distributions for WTA (Scarpa et al., 2008; Hensher and Greene, 2011). However, models in WTA space have been found to produce more realistic estimations (Train and Weeks, 2005). Therefore, the model estimation in WTA space is an important feature in our study. As an additional novelty, we allow for correlations of the random attributes, which results in a more realistic estimation of farmers' preferences for participation in a pasture grazing program. In previous studies, correlations were often not regarded (with exception of Balcombe et al., 2009, 2010; Balogh et al., 2016).

\section{MATERIALS AND METHODS}

\section{Data Collection}

For the empirical analysis, primary data were collected from German dairy farmers. An anonymous online survey was developed and available for participants from January to March 2016. Farmers were invited to participate in the survey through a mailing list of the University of Göttingen, Germany, a reference to the study in an agricultural magazine and social media channels. The surveys of 293 farmers were included in the evaluation, whereas 37 surveys could not be used because they lacked important data for the econometric analysis. The farmers needed $19 \mathrm{~min}$ on average to complete the experiment.

The questionnaire was structured as follows. First, participating farmers were asked to provide general operating data related to their farms. Second, the DCE was conducted. Next, questions were raised to identify the farmers' perceptions of different aspects of pasture grazing. Finally, socio-demographic data were collected.

\section{The Discrete Choice Experiment}

The DCE are underlying the stated preference approach, which allows for conclusions to be drawn from previously nonarticulated preferences about real choice decisions (Louviere et al., 2000). Thereby, the attributebased measure of respondents' preferences is possible through a scenario of hypothetical decision-making situations (List et al., 2006). In a DCE, participants are confronted with several choice sets consisting of different alternatives and are asked to select one of the given alternatives. Each presented alternative is characterized by pre-defined attributes and their associated levels. By systematically varying the attributes with their levels the respective influence on the selection decision can be determined (Louviere et al., 2000).

To examine the preferences of German farmers for participation in pasture grazing programs, utilization of a DCE is advisable because data about real pasture grazing programs is insufficient for an econometric analysis; thus, an experimental design is necessary to identify preferences for certain program arrangements. In doing so, initial predictions can be made on how pasture grazing programs should be designed to suit practical applications.

\section{Attributes and Levels in the Discrete Choice Experiment}

The DCE used in this investigation presented the following decision situation to the participating farmers: the farmers had to choose 1 of 2 pasture grazing programs or could decide not to participate in either (opt-out). The opt-out alternative was included because program participation is voluntary. A forced choice could lead to inaccuracy and inconsistency with demand theory (Hanley et al., 2001). Each decision situation (choice set) provided 2 different and mutually exclusive program alternatives. The programs were neutrally referred to as "pasture grazing program A" and "pasture grazing program B," so as not to reveal 
any differences with the name of the program. In each decision situation, the participating farmers chose from 2 program alternatives that were described by the following 5 attributes: program financing, annual grazing period, daily grazing period, feeding standards, and price premium. These attributes and their levels were chosen based on the premises of relevance and complexity of the experiment. Both was addressed by reviewing the literature, analyzing existing pasture grazing programs, seeking expert advice, and conducting a pilot study with 16 dairy farmers. In the pilot study, farmers were confronted with the same attributes as in the final survey. Additionally, we asked participants in the pilot study whether other variables affect the choice to participate in a pasture grazing program. By testing the suitability of the attributes in a pilot study, we followed the suggestion of Lancsar and Louviere (2008) who recommend this procedure as a promising strategy to reduce task complexity. Task complexity increases as the number of attributes, levels, or choice sets increases. This influences, on the one hand, the practicability of the experiment because complexity will result in increasing effort for participants. On the other hand, complexity can result in increasing unobserved variability (DeShazo and Fermo, 2002; Louviere et al., 2008). Therefore, it is recommendable in choice design to use only as many attributes and levels as necessary.

To ensure that farmers understood the offered attributes and levels in the DCE, we included an introduction text at the beginning of the experiment where all attributes and their characteristics were presented. The description of the attributes remained available to participants throughout the whole experiment by using mouse-over buttons in each choice set. By moving the cursor over the buttons, clarification information became visible. In this way, we ensured that the chosen attributes and levels were understood and present during the whole experiment. The introduction text for the DCE is available in Supplemental File S1 (https://doi. org/10.3168/jds.2017-12756).

Program Financing. Incentives for farmers who participate in a pasture grazing program can be designed in different ways. First, dairy companies have the possibility to pay a price premium per kilogram of raw milk to farmers producing milk on pasture. Second, as in the Netherlands, farmers who have implemented pasture grazing systems receive preferential governmental subsidies for new housing systems compared with farms without pasture grazing. Such governmental subsidies could for example be paid in the scope of the Common Agricultural Policy (Reijs et al., 2013). Another approach might be a food industry scheme, as in the German meat sector, where farmers receive bo- nus payments for the implementation of animal welfare practices (USDA, 2017). Against this background, the attribute "program financing" has the following 3 specifications: (1) food industry scheme, (2) dairy company scheme, and (3) governmental subsidies.

Annual Grazing Period. The annual grazing period in days per year is limited by the availability of grass, which is determined by the herbage growth rate, soil and climate conditions, and the individual farm area usable for pasture grazing (Van den Pol-Van Dasselaar et al., 2008). To meet the nutritional requirements of the cows and to prevent pasture degradation, access to pasture is often restricted to a period from spring to the end of autumn (Pérez-Ramírez et al., 2008; Reijs et al., 2013). However, extending the annual grazing period might reduce feed costs (Webb et al., 2005). By including the attribute "annual grazing period" in the choice sets, we aim to analyze how farmers evaluate the length of the annual grazing period. The attribute was designed with 3 levels derived from existing pasture grazing programs in the Netherlands, Germany, and Denmark (Reijs et al., 2013): 120, 150, and $180 \mathrm{~d}$ per year.

Daily Grazing Period. The daily grazing period influences the net energy intake available for milk production. Unrestricted daily grazing periods result in the lowest intake of net energy and increase the risk of large fluctuations in the composition of the diet, which becomes especially relevant if the milk yield potential rises (Van den Pol-van Dasselaar et al., 2008). Given ongoing substantial increases in annual milk production per cow (Gillespie et al., 2009; Reijs et al., 2013), an extended daily grazing period is a critical issue. In addition, the availability of grass supply as well as weather conditions determine the attractiveness of an extended daily grazing period. However, an advantage of unrestricted grazing systems is that the labor input is lower than that of restricted grazing as well as confinement systems (Van den Pol van Dasselaar et al., 2008).

A common differentiation for the length of the grazing period is the distinction between "no grazing," "restricted grazing," and "full grazing." In north-west Germany and the Netherlands, $8 \mathrm{~h}$ is the average daily grazing length in a restricted grazing system (Reijs et al., 2013). Six hours is the status quo requirement in existing pasture grazing programs in Germany (Reijs et al., 2013; Niedersächsisches Ministerium für Ernährung, Landwirtschaft und Verbraucherschutz, 2017); therefore, $8 \mathrm{~h}$ can be described as a marginal change in the requirement, which is especially valuable for analyzing and deriving implications regarding the debate on how the standards should be set for "pasture milk." Furthermore, a daily grazing period of $16 \mathrm{~h}$ was 
chosen based on the Irish circumstances. According to expert interviews, Reijs et al. (2013) determined that the average daily grazing period in Ireland is 15 to 16 $\mathrm{h}$. Thus, the analysis of how farmers evaluate an extension of the existing requirements is based the following levels for the attribute "daily grazing period": 6,8 , and $16 \mathrm{~h}$ a day.

Feeding Standards. In existing pasture grazing programs in Germany, farmers are only occasionally confronted with requirements for the feeding regimen. Therefore, the term "pasture milk" often only refers to cows having defined access to pasture, whereas the feed intake of green fodder is not prescribed. An exception is "sternenfair" milk, which prescribes a minimum quantity of green fodder in the diet as well as a limitation in the share of maize silage and concentrated feed (MVS, 2017). Switching the feeding regimen might influence the milk production inter alia in terms of the energy supplied by the diet, milk composition, physiological condition of the cows, and milk yield (Kolver and Muller, 1998; Bargo et al., 2002; Schären et al., 2016). Therefore, this may influence the costs and benefits of milk production. The aim of the attribute "feeding standard" is to evaluate the farmers' willingness to increase the share of green fodder in the diet. The requirement to supply staple feed solely consisting of green fodder thereby represents a feeding standard with $100 \%$ green fodder in the diet. Thereby, green fodder may include grass, grass silage, or hay. As the consumption of concentrated feed and maize silage reduce the intake of green fodder (Fitzgerald and Murphy, 1999), we implemented feeding standards that reduce concentrated feed in the diet by $20 \%$ or maize silage by $30 \%$. These percentages are derived from the sternenfair pasture milk program (MVS, 2017). Therefore, we analyze how farmers evaluate restrictions in their feeding regimen by including 3 specifications of the attribute "feeding standards": (1) staple feed consisting only of green fodder (grass, grass silage, or hay), (2) concentrated feed reduced by $20 \%$, and (3) amount of maize silage reduced by $30 \%$.
Price Premium. Farmers receive a premium on the producer price for raw milk to compensate the extra cost associated with the production of pasture-grazed milk. The price premium in eurocents $(\mathbf{c}) / \mathrm{kg}$ varies from $1.0,3.0$, and $5.0 \mathrm{c} / \mathrm{kg}$.

Whereas previous studies analyzing price premiums for dairy farmers chose a price range with a lower maximum price level (Schreiner and Latacz-Lohmann, 2015; Schulze and Schulz, 2013), the premiums in our DCE are chosen with regard to studies analyzing the WTP of consumers for pasture-grazed milk (Ellis et al., 2009; Wolf et al., 2011; Weinrich et al., 2014). These studies confirm that a price premium of $5.0 \mathrm{c} / \mathrm{kg}$ is realistic.

\section{Generation of Choice Sets}

The experimental design of the DCE is composed of 2 generic alternatives and 5 attributes with 3 levels each, resulting in a full-factorial design of $\left[(3 \cdot 3 \cdot 3 \cdot 3 \cdot 3)_{\text {Program A }}\right.$ $\left.\cdot(3 \cdot 3 \cdot 3 \cdot 3 \cdot 3)_{\text {Program } B}\right]=59,049$ possible decision situations or choice sets. However, for practical use, the number of choice sets was reduced by applying a so-called efficient design, because otherwise it would be too extensive. Efficient designs allow for the consideration of ex ante information and the associated uncertainty in terms of random distributions regarding the population's utility parameters. In such designs, prior parameter estimates are drawn from Bayesian parameter distributions and are therefore known as Bayesian or D-efficient designs (Rose and Bliemer, 2009). Preliminary data for our final design were collected in a pilot study with 16 dairy farmers. The D-error is used as an efficiency criterion for the efficient design as it considers the minimization of the standard errors and the covariance of the estimated utility parameters. Based on the preliminary data, a D-efficient Bayesian design (D-error of 0.078) was created using the software Ngene 1.1.2 (Choice Metrics, 2016). As a result, the number of choice sets was reduced to 12 and presented to the participating farmers in randomized order. One of these 12 choice sets is shown in Table 1 .

Table 1. Example of a choice set

\begin{tabular}{llll}
\hline Pasture attribute & $\begin{array}{l}\text { Pasture grazing } \\
\text { program A }\end{array}$ & $\begin{array}{l}\text { Pasture grazing } \\
\text { program B }\end{array}$ & Opt-out \\
\hline Program financing & $\begin{array}{l}\text { Food industry } \\
\text { scheme }\end{array}$ & Governmental subsidies & Unchanged management \\
Annual grazing period (d/yr) & 120 & 150 & \\
Daily grazing period $(\mathrm{h} / \mathrm{d})$ & 6 & 8 & \\
Feeding standards & Concentrated feed & Amount of maize silage & \\
Premium $(€$ cent $/ \mathrm{kg})$ & 3 & 5 & $\mathrm{O}$ \\
I choose: & $\mathrm{O}$ & $\mathrm{O}$ & \\
\hline
\end{tabular}




\section{Model Selection}

To derive WTA values for the attributes of the DCE and, thus, be able to give recommendations for practical use, an approach that produces realistic WTA estimates had to be found. In this context, models "in preference space" are the current state of the art method for estimating individuals' WTA. A main assumption of these models is that the price coefficient is fixed across farmers. This is necessary because otherwise the WTA is derived by calculating the ratio of 2 randomly distributed terms, namely the ratio of the distribution of the nonmonetary attribute and the distribution of the price coefficient. Unfortunately, this procedure often results in unrealistic and invalid distributions for WTA (Scarpa et al., 2008; Hensher and Greene, 2011). However, models in WTA space are able to overcome this problem because coefficients for WTA are directly estimated by re-formulating the model. In this case, assumptions regarding the distributions of WTA are made directly rather than on the attribute coefficients. It has been found that this approach produces more realistic WTA estimations than those produced in preference space (Train and Weeks, 2005). On the basis of the previous explanations, we decided to estimate a MLM in WTA space. Thereby, an advantage of the MLM framework is that it allows us to regard preference heterogeneity across farmers. As we aim for realistic estimations of farmers' preferences for participation in a pasture grazing program, we allow for correlations of the random attributes (Balcombe et al., 2009, 2010; Balogh et al., 2016). The general equations underlying the estimation process can be found in Supplemental File S2 (https://doi.org/10.3168/jds.2017-12756).

The choice experiment was analyzed with a MLM in WTA space using the software NLOGIT 5.0. Thereby, we estimate the probability of a farmer choosing a pasture grazing program. The coefficients of the model in WTA space represent the marginal WTA for each variable. For effect-coded variables, the WTA for the base level is calculated as the negative sum of the estimated WTA values of the other 2 attribute levels $\left[\mathrm{WTA}_{\text {Basic }}\right.$ $\left.=\left(-\mathrm{WTA}_{\text {Level1 }}-\mathrm{WTA}_{\text {Level2 }}\right)\right]$. A Wald test of linear restrictions confirms the linearity of the attribute "price premium" ( $P=0.197)$, allowing for estimation of the WTA values.

\section{RESULTS AND DISCUSSION}

\section{Descriptive Statistics}

Table 2 presents the descriptive statistics of our sample $(\mathrm{n}=293)$. The average respondent is $48 \mathrm{yr}$ old, whereas in the German farmer population, the average farmer is 53 yr old (AgriDirect Deutschland $\mathrm{GmbH}$, 2013) and therefore slightly older than the farmers in our sample. The majority of respondents are male farmers, but this reflects the German dairy farmer population. Ninety-eight percent are farm managers and therefore the decision-makers on the farm. More than half of the respondents have a vocational qualification in agriculture and an additional $30 \%$ hold a university degree. Therefore, the share of farmers with an academic education in our sample is higher than the German average, where only $10 \%$ have a university degree. This might be inter alia explained by the fact that we generated our sample using an online survey. Online experiments have great advantages because they are both low cost and able to reach many potential participants easily (Granello and Wheaton, 2004). However, access to the Internet and willingness to participate in an online-based experiment is, to a great extent, education-dependent (Granello and Wheaton, 2004). The average surveyed farmer cultivates 50 ha of arable land, which is more than the average dairy farmer in Germany with 29 ha (BLE, 2017a). Farmers have on average of 54 ha of grassland, of which 32 ha are suitable for grazing. The average amount of grassland per German dairy farmer is 35 ha and therefore less than in our sample. Information about the average number of hectares of grassland that is usable as pasture is unfortunately not available at the national scale. For respondents, the average number of cows is 91, yielding $8,081 \mathrm{~kg}$ of milk per cow and year, which is above the German average of 58 cows and $7,620 \mathrm{~kg}$ of milk (BLE, 2017b). Therefore, the results of our study must be interpreted with regard to the larger farm size and higher milk yield compared with the German averages. To analyze where the farms in our sample are located, we divided Germany into 4 parts: north (federal states: Lower Saxony, Schleswig-Holstein, Bremen, Hamburg), east (federal states: Brandenburg, Mecklenburg-Western Pomerania, Saxony, Saxony-Anhalt, Thuringia, Berlin), south (federal states: Baden-Wuerttemberg, Bavaria), and west (federal states: North Rhine-Westphalia, Hesse, Rhineland-Palatinate, Saarland). Compared with the location of farmers in the total population of German dairy farmers (Statistical Federal Office, 2010), the northern and western regions are slightly overrepresented in our sample (north: 25 vs. $21 \%$; west: 26 vs. 17\%), whereas the share of famers residing in the south and east are underrepresented (about 10 and $2.3 \%$ lower, respectively, in the sample than in the general population of German dairy farmers). Although the north-west region is overrepresented in our sample, about half of the farms in the general population as well as in our study are located in the south, so this group of farmers is well represented. 
Table 2. Summary statistics of respondents $(n=293)$

\begin{tabular}{|c|c|c|c|}
\hline Variable & Sample mean & $\mathrm{SD}$ & Germany $^{1}$ \\
\hline Farm acreage (total ha) & 50.15 & 115.23 & 29 \\
\hline Grassland (total ha) & 53.86 & 58.02 & 34.7 \\
\hline Grassland suitable for pasture (total ha) & 32.09 & 39.96 & - \\
\hline Herd size (no. of cows) & 91.03 & 92.03 & 58 \\
\hline Milk yield ( $\mathrm{kg}$ per cow and year) & $8,080.80$ & $1,419.82$ & 7,620 \\
\hline Age of respondent (yr) & 47.95 & 20.14 & 53 \\
\hline Farmer is female ${ }^{2}(\%)$ & 11.00 & & 8 \\
\hline Region: $\operatorname{north}^{3}(\%)$ & 25.26 & & 21 \\
\hline Herd size (no. of cows) & 154.15 & 102.79 & 88 \\
\hline Milk yield ( $\mathrm{kg}$ per cow and year) & $9,107.16$ & $1,146.41$ & 8,056 \\
\hline Region: east $^{3}(\%)$ & 1.71 & & 4 \\
\hline Herd size (no. of cows) & 288 & 284.65 & 184 \\
\hline Milk yield ( $\mathrm{kg}$ per cow and year) & 9,258 & 936.98 & 7,990 \\
\hline Region: $\operatorname{south}^{3}(\%)$ & 47.44 & & 58 \\
\hline Herd size (no. of cows) & 51.09 & 43.93 & 39 \\
\hline Milk yield ( $\mathrm{kg}$ per cow and year) & 7.362 .40 & $1,182.89$ & 7,007 \\
\hline Region: west $^{3}(\%)$ & 25.60 & & 17 \\
\hline Herd size (no. of cows) & 89.65 & 65.15 & 61 \\
\hline Milk yield ( $\mathrm{kg}$ per cow and year) & $8,321.07$ & $1,334.98$ & 7,773 \\
\hline Respondent is the manager of the farm (\%) & 98.17 & & 28 \\
\hline Farm has a successor (\%) & 39.90 & & 31 \\
\hline Farmer with degree of a technical college or university (\%) & 29.69 & & 10 \\
\hline Farmer with vocational training $(\%)$ & 68.50 & & - \\
\hline Farmer participates in a pasture grazing program (\%) & 16.04 & & - \\
\hline Farmer is willing to participate in a pasture program (\%) & 25.94 & & - \\
\hline Annual grazing period $(\mathrm{d})$ & 123.69 & 87.77 & 168 \\
\hline Daily grazing period $(\mathrm{h})$ & 7.35 & 6.09 & 13 \\
\hline
\end{tabular}

${ }^{1}$ Sources: Statistical Federal Office (2010), AgriDirect Deutschland GmbH (2013), BLE (2017a,b), DBV (2017), and MIV (2017).

${ }^{2}$ Because our sample contains almost exclusively farm managers, we compare the share of females in our sample with the share of female farm managers in the population of German farmers.

${ }^{3}$ The distribution of the federal states is as follows: north (federal states: Lower Saxony, Schleswig-Holstein, Bremen, Hamburg), east (federal states: Brandenburg, Mecklenburg-Western Pomerania, Saxony, SaxonyAnhalt, Thuringia, Berlin), south (federal states: Baden-Wuerttemberg, Bavaria), and west (federal states: North Rhine-Westphalia, Hesse, Rhineland-Palatinate, Saarland).

The average annual grazing period of our respondents is $124 \mathrm{~d}$ per year, with an average daily grazing period of $7 \mathrm{~h}$, whereas the average annual grazing period in Germany is $168 \mathrm{~d}$ per year and $13 \mathrm{~h}$ a day (MIV, 2017), considerably longer than the period for our sample population. Sixteen percent of sampled farmers already participate in a pasture grazing program, whereas an additional $26 \%$ are willing to participate in the future.

\section{Estimation Results}

The results of the MLM in WTA space with correlations are presented in Table 3 . The resulting coefficients can be interpreted as the monetary mark-up of farmers for implementing the required program attributes. First, we estimate a model only including the program attributes which were presented to farmers in the DCE (model 1). Model 1 therefore illustrates how the average participating farmer values the requirements of the pasture grazing program. However, the significant standard deviations in model 1 reveal heterogeneity around the mean of the variables "alternative specific constant
(ASC)," "annual grazing period," "daily grazing period 6 hours," "daily grazing period 16 hours," "staple feed only consisting of green fodder," and "amount of maize silage reduced by 30\%." This indicates that preferences for these variables vary widely between farmers. Therefore, they enter the model as random coefficients, whereas the variables "food industry scheme" and "governmental subsidies" are treated as fixed. To account for possible causes behind the detected heterogeneity, we analyze potentially influential factors by including interaction terms with the random coefficients (model 2 in Table 3). Nonsignificant interaction variables $(P>$ 0.1 ) were excluded from the model estimation stepwise. This includes for example interactions of the random coefficients with variables such as sex, age, education, and region. As suggested by Hensher et al. (2005), nonsignificant interaction terms have to be excluded from the estimation process as they would have an effect on all other parameter estimates of the model.

Pasture Grazing Program Versus Opt Out. The variable "ASC," which takes on a value of 1 if a pasture program is chosen and 0 if a farmer chooses the opt-out 
Table 3. Estimation results of the mixed logit model in the willingness to accept (WTA) space $(\mathrm{n}=293)^{1}$

\begin{tabular}{|c|c|c|}
\hline \multirow[b]{2}{*}{ Variable } & \multicolumn{2}{|c|}{ Coefficient } \\
\hline & Model 1 & Model 2 \\
\hline \multicolumn{3}{|l|}{ Program attribute } \\
\hline ASC & 0.374 & 1.118 \\
\hline Food industry scheme ${ }^{2}$ & -0.062 & -0.058 \\
\hline Governmental subsidies $^{2}$ & 0.006 & -0.001 \\
\hline Annual grazing period ${ }^{3}$ & $-3.120^{* * *}$ & $3.156 \dagger$ \\
\hline Daily grazing period $6 \mathrm{~h}^{4}$ & $1.748^{* * *}$ & $1.564^{* * *}$ \\
\hline Daily grazing period $16 \mathrm{~h}^{4}$ & $-3.016^{* * *}$ & $-2.724^{* * *}$ \\
\hline Staple feed only consisting of green fodder ${ }^{5}$ & $-1.351^{* * *}$ & 1.719 \\
\hline Amount of maize silage reduced by $30 \%^{5}$ & $0.898^{* * *}$ & $-1.331 \dagger$ \\
\hline \multicolumn{3}{|l|}{ Interaction term } \\
\hline Annual grazing period $^{3} \times$ willingness to participate $^{6}$ & & $1.126^{* * *}$ \\
\hline Annual grazing period ${ }^{3} \times$ milk yield $^{7}$ & & $-0.704^{* * *}$ \\
\hline Annual grazing period ${ }^{3} \times$ herd size & & $-0.013^{* * *}$ \\
\hline Annual grazing period ${ }^{3} \times$ pasture land & & $0.028^{* * *}$ \\
\hline Daily grazing period $6 \mathrm{~h}^{4} \times$ willingness to participate ${ }^{6}$ & & $-0.386^{* * *}$ \\
\hline Daily grazing period $16 \mathrm{~h}^{4} \times$ willingness to participate ${ }^{6}$ & & $0.442^{* * *}$ \\
\hline Staple feed only consisting of green fodder ${ }^{5} \times$ milk yield $^{7}$ & & $-0.350^{*}$ \\
\hline Staple feed only consisting of green fodder ${ }^{5} \times$ herd size & & $-0.011^{* * *}$ \\
\hline Staple feed only consisting of green fodder ${ }^{5} \times$ pasture land & & $0.021^{* * *}$ \\
\hline Amount of maize silage reduced by $30 \%^{5} \times$ milk yield $^{7}$ & & $0.280^{* * *}$ \\
\hline \multicolumn{3}{|l|}{ SD of random parameters } \\
\hline SD ASC & $7.301^{* * *}$ & $7.494^{* * *}$ \\
\hline SD annual grazing period & $0.045^{* * *}$ & $0.033^{* * *}$ \\
\hline SD daily grazing period $6 \mathrm{~h}$ & $1.219^{* * *}$ & $1.185^{* * *}$ \\
\hline SD daily grazing period $16 \mathrm{~h}$ & $1.996^{* * *}$ & $1.970^{* * *}$ \\
\hline SD staple feed only consisting of green fodder & $2.472^{* * *}$ & $2.315^{* * *}$ \\
\hline SD amount of maize silage reduced by $30 \%$ & $1.667^{* * *}$ & $1.488^{* * *}$ \\
\hline \multicolumn{3}{|l|}{ Goodness of fit } \\
\hline Log-likelihood & $-2,368.55$ & $-2,327.39$ \\
\hline $\mathrm{AIC}$ & $4,797.10$ & $4,734.80$ \\
\hline \multicolumn{3}{|c|}{${ }^{1} \mathrm{ASC}=$ alternative specific constant; $\mathrm{AIC}=$ Akaike information criterion. } \\
\hline \multicolumn{3}{|c|}{${ }^{2}$ Effect-coded variable; base level is "dairy company scheme." } \\
\hline \multicolumn{3}{|l|}{$\begin{array}{l}{ }^{3} \text { Annual grazing period of } 120 \mathrm{~d} \text {. The WTA per day can be calcula } \\
{ }^{4} \text { Effect-coded variable; base level is "daily grazing period } 8 \text { hours." }\end{array}$} \\
\hline${ }^{4}$ Effect-coded variable; base level is "daily grazing period $8 \mathrm{~h}$ & & \\
\hline \multicolumn{3}{|c|}{${ }^{5}$ Effect-coded variable; base level is "concentrated feed reduced by $20 \% . "$} \\
\hline \multicolumn{3}{|c|}{${ }^{6}$ Effect-coded variable; base level is "not willing to participate in a pasture grazing program." } \\
\hline \multicolumn{3}{|c|}{${ }^{7}$ Unit of "milk yield" is $1,000 \mathrm{~kg}$. } \\
\hline${ }^{* * *} P<0.001 ; * * P<0.01 ; * P<0.05 ; \dagger P<0.1$; number of & n draws $=50$ & ly significant \\
\hline
\end{tabular}

alternative, gives information about the general preference of a farmer to participate in a pasture grazing program. As shown in Table 3, the ASC in both estimated models is not significant. Therefore, the farmers in our sample reveal, ceteris paribus, no significant general WTA participation in a pasture grazing program over the opt-out. The insignificant ASC further reveals that there are no omitted variables (attributes, levels, or sociodemographic factors) which would have had an effect on the choice to participate in the offered programs (Adamowicz et al., 1998; Meyerhoff and Liebe, 2009).

Program Financing. The coefficients for the effectcoded variables "food industry scheme" and "governmental subsidies" are not significant in both estimated models. This means that farmers have no significant preference whether the pasture grazing program is fi- nanced by the food industry, a governmental scheme, or the dairy company, which was the reference level of the effect-coded variable. Given this finding, both the government and the food industry should be encouraged to initiate additional pasture grazing programs.

Grazing Period. If the average farmer (represented by model 1) is willing to participate in a pasture grazing program with an annual grazing period of $120 \mathrm{~d}$, the price premium has to be $3.12 \mathrm{c} / \mathrm{kg}$. Confirmed by a Wald test for linear restrictions the variable "annual grazing period" ( $P=0.398)$ is included in the model estimations as a linear term. Therefore, the WTA of farmers increases with every additional day of required pasture access by $0.026 \mathrm{c} / \mathrm{kg}$. Consequently, the willingness to accept an annual grazing period of 150 and $180 \mathrm{~d}$ is $3.90 \mathrm{c} / \mathrm{kg}(-3.90=-0.026 \cdot 150)$ and $4.68 \mathrm{c} /$ 
$\mathrm{kg}(-4.68=-0.026 \cdot 180)$, respectively. Due to climate conditions, the annual grazing period is often restricted to a period from spring to the end of autumn (PérezRamírez et al., 2008). Thus, meeting the nutritional requirements of the cows and preventing pasture degradation becomes more difficult if the required annual grazing period is extended (Van den Pol-van Dasselaar et al., 2008; Legrand et al., 2009; Schären et al., 2016). Therefore, pasture grazing programs aiming at an extension of the annual grazing period have to be endowed with higher budgets to pay appropriate price premiums for farmers.

As we cannot confirm the linearity of the variable "daily grazing period" $(P \leq 0.001)$, it is included as an effect-coded variable in the model estimation. The significant positive coefficient of the variable "daily grazing period 6 hours" indicates that the WTA of farmers decreases by $1.75 \mathrm{c} / \mathrm{kg}$ if he or she can choose a pasture grazing program with a daily grazing period of $6 \mathrm{~h}$. A daily grazing period of $8 \mathrm{~h}$ decreases the price demand of farmers by $1.27 \mathrm{c} / \mathrm{kg}[1.27=-(1.75-3.02)]$. However, for a grazing period of $16 \mathrm{~h}$, the average farmer requires a price premium of $3.02 \mathrm{c} / \mathrm{kg}$. Therefore, a daily grazing period of $6 \mathrm{~h}$ results in a lower price demand compared with daily grazing periods of 8 or $16 \mathrm{~h}$. More precisely, the farmers' marginal WTA for a daily grazing period of 8 or $16 \mathrm{~h}$ instead of $6 \mathrm{~h}$ is $0.48 \mathrm{c} / \mathrm{kg}$ $(0.48=1.75-1.27)$ or $4.77 \mathrm{c} / \mathrm{kg}(4.77=1.75+3.02)$, respectively.

Altogether, we can determine a range for price premiums related to the length of the grazing period lying between $1.37 \mathrm{c} / \mathrm{kg}(-1.37=-3.12+1.75)$ for the shortest grazing period of $120 \mathrm{~d}$ per year and $6 \mathrm{~h}$ per day and $7.70 \mathrm{c} / \mathrm{kg}(-7.70=-4.68-3.02)$ for the longest grazing period of $180 \mathrm{~d}$ and $16 \mathrm{~h}$. The results indicate that farmers are more motivated to participate in pasture grazing programs when shorter grazing periods are required.

At the time of the survey, farmers received an average milk price of $28 \mathrm{c} / \mathrm{kg}$ (Statista, 2017). The price premiums farmers currently receive for producing pasture-grazed milk are in the range of 0.5 to 1.5 eurocent for pasture access of $120 \mathrm{~d}$ per year and $6 \mathrm{~h}$ a day (FrieslandCampina, 2017). In the federal state Lower Saxony, a pasture milk label has been initiated, which aims to pay farmers a price premium of $5 \mathrm{c} / \mathrm{kg}$ for a pasture access of $120 \mathrm{~d} / \mathrm{yr}$ and $6 \mathrm{~h} / \mathrm{d}$ (Niedersächsisches Ministerium für Ernährung, Landwirtschaft und Verbraucherschutz, 2017). Therefore, the estimated WTA of farmers seems to be realistic.

Additionally, existing consumer studies estimate that the WTP for pasture-grazed milk is 10 and $40 \mathrm{c} / \mathrm{kg}$ higher than conventional milk prices (Wolf et al., 2011; Weinrich et al., 2014). This WTP seems to be high enough to cover the price premiums required by farmers to implement a prescribed grazing period. However, it has to be considered that the WTP determined in the cited studies might be affected by the so-called citizenconsumer gap. This gap describes the issue that people as citizens may favor the production of milk from pasture-grazed cows and therefore state a high WTP for this production method; however, as consumers, they still buy conventional milk produced in a system where cows have no access to pasture, which is cheaper than their stated WTP (Verbeke et al., 2010).

Farmers with an aversion to participate in a pasture grazing program have a significantly higher WTA for the variable "annual grazing period" compared with farmers who already participate or are interested in participating in such a program (the interaction term "annual grazing period $\times$ willingness to participate" in model 2 in Table 3 is significantly positive). In addition, farmers who have an aversion to program participation have a higher preference for programs with a daily grazing period of $6 \mathrm{~h}$ and a significantly higher WTA for a daily grazing period of $16 \mathrm{~h}$ compared with farmers with a preference for program participation. As a result, the general willingness to participate significantly influences the price premium demanded by farmers. In this context, we suggest putting emphasis on existing pasture grazing programs. Indeed, from the descriptive statistics, it appears that more than half of the farmers have an aversion to program participation. Thus, to make programs more attractive, dairies should revise their existing programs based on the results of this study. However, the general willingness to participate in a pasture grazing program might be determined by factors such as committed assets and opportunity costs. Committed assets are especially relevant for farms that have aligned their production to a confinement system with zero pasture access. Integrating pasture use into these systems could result in high costs for farmers. Opportunity costs may become relevant, for example, if nonspecialized farms with other types of production (e.g., arable farming) and a limited amount of pasture have to convert land to pasture. Considering these aspects is an important issue in the evaluation of our results.

Furthermore, the results reveal that a higher annual milk yield per cow increases the price demand of farmers for the variable "annual grazing period." For example, the price demand for an annual grazing period of $120 \mathrm{~d}$ increases by $0.70 \mathrm{c} / \mathrm{kg}$ if the annual milk yield per cow rises by 1,000 kg. Consequently, the higher the farm 
milk yield, the less a farmer is willing to participate in a pasture grazing program prescribing an annual grazing period.

Herd size also has a notable effect on the price premium farmers require for a prescribed annual grazing period, implying that a greater number of cows proportionally increases the price demand. Thus, farms with fewer cows are more likely to participate in a pasture grazing program. This is related to the fact that the number of hectares needed for pasture grazing as well as the average walking distance between pasture and milking parlor proportionally increase with the herd size (Van den Pol-van Dasselaar et al., 2008; Burow et al., 2013). Consequently, an increased number of cows makes grazing management more difficult by decreasing labor efficiency and increasing the costs for pasture land. Both factors are reflected in the price demand of farmers. However, every additional hectare of available pasture land decreases the willingness to accept an annual grazing period. Supported by the findings of Gillespie et al. (2009), who identified grazing farms as having greater noncrop areas, we state that farmers' willingness to accept program participation is influenced by their acreage of suitable pasture.

From these results, the following policy implications can be derived. The first focuses on the objective to counteract the trend of declining pasturing in Germany (Reijs et al., 2013). In this context, it is important to make pasture grazing attractive to as many farms as possible. Therefore, program participation should be accessible for both small and large farms. For large farms, it is difficult to convert to pasture grazing because of high transformation costs, committed assets, potential losses in milk yield, and increasing efforts in management. However, providing flexible program options might be a promising strategy to enable large herds to implement pasture grazing. For example, farmers could receive a price premium for partial pasture access, in which pasture grazing is mandatory for at least $25 \%$ of the dairy cows for a minimum of $120 \mathrm{~d}$ (FrieslandCampina, 2017). In this way, farmers who have restricted access to pasture also have the chance to participate in a pasture grazing program.

Another implication of our results is based on the objective to meet the demand of consumers for pasture grazed milk. Therefore, program design may focus on smaller-scale farmers with lower milk yields, who have easier access to pasture and were detected to demand lower price premiums to accept pasture grazing requirements. Analyzing the potential of specialized pasture grazing programs is an issue for further research.

Feeding Standards. The participating farmers declined the option of a feeding standard prescribing the use of only green fodder (grass, grass silage, or hay) when given the alternative of a requirement that reduces the amount of concentrated feed or maize silage in the diet. On average, farmers assess a reduction in the amount of concentrated feed and the amount of maize silage by $30 \%$ as an acceptable feeding standard, which is indicated by the positive sign of both variables [the WTA for the variable "concentrated feed reduced by $20 \%$ " is $0.45 \mathrm{c} / \mathrm{kg}(0.45=1.35-0.90)]$. Consequently, the marginal willingness to accept the feeding standard "staple feed only consisting of green fodder" relative to a reduction in the use of concentrated feed by $20 \%$ and a reduction in the amount of maize silage by $30 \%$ is $1.80 \mathrm{c} / \mathrm{kg}(1.80=1.35+0.45)$ and $2.25 \mathrm{c} / \mathrm{kg}(2.25$ $=1.35+0.9)$.

Farmers show a significantly higher acceptance for the feeding standard "staple feed only consisting of green fodder" if their milk yields are below the sample average. In contrast, an increasing milk yield raises the farmers' preference for both of the other feeding standards. Thus, it is more difficult to motivate farmers with high yielding cows to fulfill the requirement "staple feed only consisting of green fodder." According to O'Mara et al. (1998) and Fitzgerald and Murphy (1999), substitution of grass silage with maize silage potentially leads to higher feed intake, milk production, and milk protein concentration. This may explain the aversion of farmers to a complete abandonment of maize silage. In addition, a high supply of grass without feeding any supplements may result in large fluctuations in the composition of the diet and therefore affects milk production (Bargo et al., 2002; Schären et al., 2016). Thus, feeding solely green fodder results in lower milk productivity and therefore financial losses, which have to be recovered by paying a price premium to farmers. However, feeding a high share of grass increases the concentration of valuable linolenic acid (LNA) and Q-linolenic acid (ALA), which pertain to the class of essential fatty acids and can therefore not be synthesized by the human body (Stark et al., 2008). Stockdale et al. (2003) showed that feeding fresh pasture alone increases the concentration of valuable LNA, whereas grain concentrates have the opposite effect. Thus, the level of UFA is significantly higher in pasture-based diets compared with TMR diets containing maize silage (Bargo et al., 2002; Croissant et al., 2007). Because LNA contains conjugated unsaturated double bonds, it is anti-carcinogenic and has cardio-protective effects (Djousse et al., 2005). In this way, pasture-grazed milk has higher nutritional value for consumers, which may provide marketing opportunities for pasture-grazed milk. Therefore, paying price premiums to farmers for increasing the content of LNA and ALA may result 
in an economic benefit for farmers and simultaneously meet the demand of consumers for products with high nutritional value and sensory quality. However, the positive effects on LNA and ALA are mainly present if fresh grass is included in the diet (Chilliard et al., 2001; Bargo et al., 2006). In Germany, as well as in most other European countries, pasture access is not possible during the whole year due to climate conditions. Rather, a supply of grass is only available from spring to autumn. Therefore, one implication might be that farmers could sell pasture milk only in the summer and, for example, hay milk or milk produced only from green fodder in the winter. As this would imply a change from year-round to seasonal marketing, the mentioned approach would result in higher efforts and costs on the production level and therefore higher prices for consumers. Moreover, introducing seasonal pasture milk could potentially lead to confusion and mistrust among consumers. Therefore, analyzing the potential and limitations of seasonal marketing of pasture-grazed milk as well as the acceptance of different feeding standards are important issues for further research.

\section{CONCLUSIONS}

This paper contributes to the literature on German farmers' willingness to participate in pasture grazing programs and the price premiums they demand for several program requirements. This research adds to the literature analyzing preferences through the utilization of a DCE. The central result of this investigation is that farmers require significant price premiums for program participation. Therefore, price premiums have to be higher if longer grazing periods are prescribed. Furthermore, the inclusion of a feeding standard that requires a staple feed consisting solely of green fodder results in farmers demanding a significantly higher price premium. The price demanded by farmers is highly influenced by the individual farm milk yield, the number of cows, the amount of pasture land, and the general willingness of farmers to participate in a pasture grazing program. To motivate farmers to continue or even extend pasture grazing, future program design could use the estimated price premiums demanded by farmers from this study. Future research could validate our results by repeating the experiment at a later time to examine whether farmers' decision-making behavior changes under different market conditions. Additionally, other preference-related aspects could be included in the experiment, such as statements about the motivation of farmers to use pasture and participate in pasture grazing programs. Furthermore, it would be helpful to compare pasture grazing programs and farm- ers' motives by conducting additional experiments in an international context involving farmers in different regions with varying degrees of suitability and utilization of pasture grazing.

\section{ACKNOWLEDGMENTS}

The authors thank 2 anonymous referees and the editor for helpful comments and suggestions.

\section{REFERENCES}

Adamowicz, W. L., P. C. Boxall, M. Williams, and J. J. Louviere. 1998. Stated preference approaches for measuring passive use values: Choice experiments and contingent valuation. Am. J. Agric. Econ. 80:64-75. https://doi.org/10.2307/3180269.

AgriDirect Deutschland GmbH. 2013. Jahresübersicht: Pressemitteilung 2013. Accessed Feb. 1, 2017. https://issuu.com/agridirect/docs/ pressemitteilungen_2013.

Balcombe, K., A. Chalak, and I. Fraser. 2009. Model selection for the mixed logit with Bayesian estimation. J. Environ. Econ. Manage. 57:226-237. https://doi.org/10.1016/j.jeem.2008.06.001.

Balcombe, K., I. Fraser, and S. Di Falco. 2010. Traffic lights and food choice: A choice experiment examining the relationship between nutritional food labels and price. Food Policy 35:211-220. https:// doi.org/10.1016/j.foodpol.2009.12.005.

Balogh, P., D. Békési, M. Gorton, J. Popp, and P. Lengyel. 2016. Consumer willingness to pay for traditional food products. Food Policy 61:176-184. https://doi.org/10.1016/j.foodpol.2016.03.005.

Bargo, F., J. E. Delahoy, G. F. Schroeder, L. H. Baumgard, and L. D. Muller. 2006. Supplementing total mixed rations with pasture increase the content of conjugated linoleic acid in milk. Anim. Feed Sci. Technol. 131:226-240. https://doi.org/10.1016/j. anifeedsci.2006.04.017.

Bargo, F., L. D. Muller, J. E. Delahoy, and W. T. Cassidy. 2002. Milk response to concentrate supplementation of high producing dairy cows grazing at two pasture allowances. J. Dairy Sci. 85:17771792. https://doi.org/10.3168/jds.S0022-0302(02)74252-5.

Bundesministerium für Landwirtschaft und Ernährung (BLE). 2017a. Buchführungsergebnisse der Testbetriebe 2015/16. Accessed Feb. 10, 2017. http://www.bmel-statistik.de/landwirtschaft/ testbetriebsnetz-landwirtschaft-buchfuehrungsergebnisse/ buchfuehrungsergebnisse-landwirtschaft/.

Bundesministerium für Landwirtschaft und Ernährung (BLE). 2017b. Milchleistung je Kuh in Deutschland in den Jahren 1900 bis 2015 (in Kilogramm). Accessed Feb. 10, 2017. https://de.statista. com/statistik/daten/studie/153061/umfrage/durchschnittlichermilchertrag-je-kuh-in-deutschland-seit-2000.

Burow, E., T. Rousing, P. T. Thomsen, N. D. Otten, and J. T. Sorensen. 2013. Effect of grazing on the cow welfare of dairy herds evaluated by a multidimensional welfare index. Animal 7:834-842. https://doi.org/10.1017/S1751731112002297.

Chilliard, Y., A. Ferlay, and M. Doreau. 2001. Effect of different types of forages, animal fat or marine oils in cow's diet on milk fat secretion and composition, especially conjugated linoleic acid (CLA) and polyunsaturated fatty acids. Livest. Prod. Sci. 70:31-48. https://doi.org/10.1016/S0301-6226(01)00196-8.

Choice Metrics. 2016. NGENE download. Accessed Jan. 8, 2016. http://www.choice-metrics.com/download.html.

Christensen, T., A. Pedersen, H. O. Nielsen, M. R. Mørkbak, and B. Hasler. 2011. Determinants of farmers' willingness to participate in subsidy schemes for pesticide-free buffer zones: A choice experiment study. Ecol. Econ. 70:1558-1564. https://doi.org/10.1016/j. ecolecon.2011.03.021.

Croissant, A. E., S. P. Washburn, L. L. Dean, and M. A. Drake. 2007. Chemical properties and consumer perception of fluid milk from 
conventional and pasture-based production systems. J. Dairy Sci. 90:4942-4953. https://doi.org/10.3168/jds.2007-0456.

DeShazo, J., and G. Fermo. 2002. Designing choice sets for stated preference methods: The effects of complexity on choice consistency. J. Environ. Econ. Manage. 44:123-143.

Deutscher Bauernverband (DBV). 2017. Situationsbericht 2016/17. Accessed May 12, 2017. http://www.bauernverband.de/ situationsbericht-2016-17.

Djousse, L., D. K. Arnett, J. J. Carr, J. H. Eckfeldt, P. N. Hopkins, M. A. Province, and R. C. Ellison. 2005. Dietary linolenic acid is inversely associated with calcified atherosclerotic plaque in the coronary arteries: The National Heart, Lung, and Blood Institute Family Heart Study. Circulation 111:2921-2926. https://doi. org/10.1161/CIRCULATIONAHA.104.489534.

Ellis, K. A., K. Billington, B. McNeil, and D. McKeegan. 2009. Public opinion on UK milk marketing and dairy cow welfare. Anim. Welf. 18:267-282.

Fitzgerald, J., and J. Murphy. 1999. A comparison of low starch maize silage and grass silage and the effect of concentrate supplementation of the forages or inclusion of maize grain with the maize silage on milk production by dairy cows. Livest. Prod. Sci. 57:95-111. https://doi.org/10.1016/S0301-6226(98)00200-0.

FrieslandCampina. 2017. Milk price explained-2017. Accessed Feb. 10, 2017. https://www.frieslandcampina.com/en/organisation/ financials/milk-price-explained/.

Gillespie, J., and R. Nehring. 2014. Pasture-based versus conventional milk production: Where is the profit? J. Agric. Appl. Econ. $46: 543-558$.

Gillespie, J., R. Nehring, C. Hallahan, and C. Sandretto. 2009. Pasture-based dairy systems: Who are the producers and are their operations more than conventional dairies? J. Agric. Resour. Econ. $34: 412-427$.

Government Accountability Office. 2009. Retail food prices grew faster than the prices farmers received for agriculture commodities. GAO-09-746R. L. R. Shames, Washington, DC.

Granello, D. H., and J. E. Wheaton. 2004. Online data collection: Strategies for research. J. Couns. Dev. 82:387-393. https://doi. org/10.1002/j.1556-6678.2004.tb00325.x.

Hanley, N., S. Mourato, and R. E. Wright. 2001. Choice modelling approaches: A superior alternative for environmental valuation? J. Econ. Surv. 15:435-462. https://doi.org/10.1111/1467-6419.00145.

Hensher, D. A., and W. H. Greene. 2011. Valuation of travel time savings in WTP and preference space in the presence of taste and scale heterogeneity. J. Transp. Econ. Policy 45:505-525.

Hensher, D. A., J. M. Rose, and W. H. Greene. 2005. Applied Choice Analysis: A Primer. Cambridge Univ. Press, Cambridge, UK. https://doi.org/10.1017/CBO9780511610356.

Kolver, E. S., and L. D. Muller. 1998. Performance and nutrient intake of high producing Holstein cows consuming pasture or a total mixed ration. J. Dairy Sci. 81:1403-1411. https://doi.org/10.3168/ jds.S0022-0302(98)75704-2.

Lancsar, E., and J. Louviere. 2008. Conducting discrete choice experiments to inform healthcare decision making. Pharmacoeconomics 26:661-677. https://doi.org/10.2165/00019053-200826080-00004.

Legrand, A. L., M. A. G. von Keyserlingk, and D. M. Weary. 2009. Preference and usage of pasture versus free-stall housing by lactating dairy cattle. J. Dairy Sci. 92:3651-3658. https://doi. org/10.3168/jds.2008-1733.

List, J. A., P. Sinha, and M. H. Taylor. 2006. Using choice experiments to value non-market goods and services: Evidence from field experiments. Adv. Econ. Anal. Policy 6:1-37. https://doi. org/10.2202/1538-0637.1132.

Louviere, J. J., D. A. Hensher, and J. D. Swait. 2000. Stated choice methods: Analysis and applications. Cambridge University Press, Cambridge, New York, NY.

Louviere, J. J., T. Islam, N. Wasi, D. Street, and L. Burgess. 2008. Designing discrete choice experiments: Do optimal designs come at a price? J. Consum. Res. 35:360-375. https://doi. org $/ 10.1086 / 586913$.

Luce, R. D. 1959. Individual Choice Behavior: A Theoretical Analysis. Wiley, New York, NY.
McFadden, D. 1974. Conditional logit analysis of qualitative choice behavior. Frontiers in Econometrics 105-142.

Meyerhoff, J., and U. Liebe. 2009. Status quo effect in choice experiments: Empirical evidence on attitudes and choice task complexity. Land Econ. 85:515-528. https://doi.org/10.3368/le.85.3.515.

Milchindustrie-Verband (MIV). 2017. Wie werden Kühe gehalten? Accessed May 15, 2017. http://www.meine-milch.de/artikel/wiewerden-k\%C3\%BChe-gehalten.

MVS. 2017. Sternenfair: Unsere 5-Sterne-Philosophie. Accessed Feb. 1 , 2017. http://www.sternenfair.de/sternenfair/philosophie.php.

Niedersächsisches Ministerium für Ernährung, Landwirtschaft und Verbraucherschutz. 2017. Das Niedersächsische Weidemilchprogramm. Accessed May 15, 2017. http:// www.ml.niedersachsen.de/themen/landwirtschaft/tierische_ produktion/das-niedersaechsische-weidemilchprogramm-145663. html.

O’Mara, F. P., J. J. Fitzgerald, J. J. Murphy, and M. Rath. 1998. The effect on milk production of replacing grass silage with maize silage in the diet of dairy cows. Livest. Prod. Sci. 55:79-87. https:// doi.org/10.1016/S0301-6226(98)00115-8.

Pérez-Ramírez, E., R. Delagarde, and L. Delaby. 2008. Herbage intake and behavioural adaptation of grazing dairy cows by restricting time at pasture under two feeding regimes. Animal 2:1384-1392. https://doi.org/10.1017/S1751731108002486.

Reijs, J. W., C. Daatselaar, and J. Helming. 2013. Grazing dairy cows in North-West Europe: Economic farm performance and future developments with emphasis on the Dutch situation. [Electronic ed.]. Report/LEI 2013-001. LEI Wageningen UR, The Hague.

Rose, J. M., and M. C. J. Bliemer. 2009. Constructing efficient stated choice experimental designs. Transp. Rev. 29:587-617. https://doi. org $/ 10.1080 / 01441640902827623$

Scarpa, R., M. Thiene, and K. Train. 2008. Utility in willingness to pay space: A tool to address confounding random scale effects in destination choice to the Alps. Am. J. Agric. Econ. 90:994-1010. https://doi.org/10.1111/j.1467-8276.2008.01155.x.

Schären, M., S. Jostmeier, S. Ruesink, L. Hüther, J. Frahm, M. Bulang, U. Meyer, J. Rehage, J. Isselstein, G. Breves, and S. Dänicke. 2016. The effects of a ration change from a total mixed ration to pasture on health and production of dairy cows. J. Dairy Sci. 99:1183-1200. https://doi.org/10.3168/jds.2015-9873.

Schreiner, J. A., and U. Latacz-Lohmann. 2015. Farmers' valuation of incentives to produce genetically modified organism-freemilk: Insights from a discrete choice experiment in Germany. J. Dairy Sci. 98:7498-7509. https://doi.org/10.3168/jds.2015-9515.

Schulz, N., G. Breustedt, and U. Latacz-Lohmann. 2014. Assessing farmers' willingness to accept "greening": Insights from a discrete choice experiment in Germany. J. Agric. Econ. 65:26-48. https:// doi.org/10.1111/1477-9552.12044.

Schulze, B., and N. Schulz. 2013. Integrating economic and behavioural theory to explain dairy farmers' contract acceptance: Pages 135-163 in Discrete Choice Experimente zur Prognose des Entscheidungsverhaltens bei Landwirten. Dissertation. Univ. Kiel, Germany.

Slots, T., G. Butler, C. Leifert, T. Kristensen, L. H. Skibsted, and J. H. Nielsen. 2009. Potentials to differentiate milk composition by different feeding strategies. J. Dairy Sci. 92:2057-2066. https:// doi.org/10.3168/jds.2008-1392.

Stark, A. H., M. A. Crawford, and R. Reifen. 2008. Update on alphalinolenic acid. Nutr. Rev. 66:326-332. https://doi.org/10.1111/ j.1753-4887.2008.00040.x.

Statista. 2017. Preis von Kuhmilch in Deutschland von Februar 2014 bis Februar 2017 (in Euro je 100 Kilogramm). Accessed May 15, 2017. https://de.statista.com/statistik/daten/studie/380546/ umfrage/preis-von-kuhmilch-in-deutschland/.

Statistical Federal Office. 2010. Landwirtschaftszählung 2010: Weidehaltung von Milchkühen auf Betriebsflächen nach Bestandsgrößenklassen und Bundesländern 2009. Accessed May 15, 2017. https://www.destatis.de/DE/ZahlenFakten/ Wirtschaftsbereiche/LandForstwirtschaftFischerei/ Landwirtschaftszaehlung $2010 /$ Tabellen/9_4 WeidehaltungMilchkuehe.html. 
Stockdale, C. R., G. P. Walker, W. J. Wales, D. E. Dalley, A. Birkett, Z. Shen, and P. T. Doyle. 2003. Influence of pasture and concentrates in the diet of grazing dairy cows on the fatty acid composition of milk. J. Dairy Res. 70:267 https://doi.org/10.1017/ S0022029903006009.

Tozer, P. R., F. Bargo, and L. D. Muller. 2003. Economic analyses of feeding systems combining pasture and total mixed ration. J. Dairy Sci. 86:808-818. https://doi.org/10.3168/jds.S00220302(03)73663-7.

Train, K., and M. Weeks. 2005. Discrete choice models in preference space and willingness-to-pay space. Appl. Sim. Method. Environ. Res. Econ. 6:1-16.

USDA. 2017. Broad Initiative to Increase Animal Welfare. Accessed Feb. 4, 2017. http://www.fas.usda.gov/data/germany-broadinitiative-increase-animal-welfare.

Van den Pol-Van Dasselaar, A., T. V. Vellinga, A. Johansen, and E. Kennedy. 2008. To graze or not to graze, that's the question. Grassl. Sci. Eur. 13:706-716.

Verbeke, W., F. J. A. Perez-Cueto, M. D. d. Barcellos, A. Krystallis, and K. G. Grunert. 2010. European citizen and consumer attitudes and preferences regarding beef and pork. Meat Sci. 84:284-292. https://doi.org/10.1016/j.meatsci.2009.05.001.

Webb, J., S. G. Anthony, L. Brown, H. Lyons-Visser, C. Ross, B. Cottrill, P. Johnson, and D. Scholefield. 2005. The impact of increasing the length of the cattle grazing season on emissions of ammonia and nitrous oxide and on nitrate leaching in England and Wales. Agric. Ecosyst. Environ. 105:307-321. https://doi. org/10.1016/j.agee.2004.02.003

Weinrich, R., S. Kühl, A. Zühlsdor, and S. Spiller. 2014. Consumer attitudes in Germany towards different dairy housing systems and their implications for the marketing of pasture raised milk. Int. Food Agribus. Manag. Rev. 17:205-222.

White, S. L., G. A. Benson, and S. P. Washburn. 2002. Milk production and economic measures in confinement or pasture systems using seasonally calved Holstein and Jersey cows. J. Dairy Sci. 85:95-104. https://doi.org/10.3168/jds.S0022-0302(02)74057-5.

Wolf, C. A., G. T. Tonsor, and N. J. Olynk. 2011. Understanding US consumer demand for milk production attributes. J. Agric. Resour. Econ. 36:326-342. 